TechnoLEARN: An International Journal of Educational Technology

TechnoLEARN: 9(2): 87-89, December 2019

DOI: $10.30954 / 2231-4105.02 .2019 .5$

(O2019 New Delhi Publishers. All rights reserved

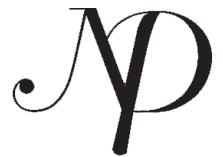

\title{
Professional Ethics in Teacher Education
}

\author{
Atul Gurtu \\ Astt. Prof. K.P. Training College, Allahabad, Uttar Pradesh, India \\ Corresponding author: atulgurtukptc@rediffmail.com
}

\begin{abstract}
Teachers play a pivotal role as front liners in every education system. Their role is not simply that of disseminating knowledge or imparting information but also to provide good quality education. For providing this one has to professionally competent and up to date in its profession, and has to follow certain rules or code of conduct known as professional ethics. In teaching there are basically three pillars which interact with each other i.e. teacher, student, and society. This paper discusses all three types of obligations faced by the teacher in teacher education i.e. Obligations towards Students, Obligations towards Society, Obligations towards the Profession.
\end{abstract}

Keywords: Professional ethics, Obligations, composite culture, Stake holders

Teachers play a pivotal role as front liners in every education system. Their role is not simply that of disseminating knowledge or imparting information but also to provide good quality education. We all are aware of the fact, that our main responsibility is to the student and to the development of his/her full potential. In this respect we need to pursue the truth, devote all our efforts towards excellence, the acquisition of knowledge and the observance of democratic principles. It is our duty to maintain a high level of competence and in order to do this we need to engage in continuous professional development throughout our career in the profession so that we can perform our tasks effectively in the classroom, school and wider community.

\section{Meaning of Professional Ethics}

Professional ethics encompass the personal, organizational and corporate standards of behavior expected of professionals or in other simple words professional ethics are certain rules and regulations followed by professionals and it is the most important identifying feature of their profession. In teaching there are basically three pillars which interact with 
cp

Gurtu

each other i.e., teacher, student, and society. All of us are aware that our main responsibility is to the student and to the development of his/her full potential. In this respect we need to devote all our efforts towards excellence, the acquisition of knowledge and the observance of democratic principles. It is our duty to maintain a high level of competence and in order to do this we need to engage in continuous professional development throughout our career so that we could follow our ethics to the T. The Code of Professional Ethics for teachers provides a framework of principles to guide them in discharging their obligations towards students, parents, colleagues and community. Increased awareness of the ethical principles governing the teaching profession is essential to ensure professionalism' among teachers.

\section{Obligations towards Students}

Treats all students with love and affection.

* Respects the value of being just and impartial to all students irrespective of their caste, creed, religion, sex, economic status, disability, language and place of birth .

* Facilitates students' physical, social, intellectual, emotional, and moral development .

Respects basic human dignity of the child in all aspects of school life.

Makes planned and systematic efforts to facilitate the child to actualize his/her potential and talent.

* Transacts the curriculum in conformity with the values enshrined in the Constitution of India.

* Adapts his/her teaching to the individual needs of students.

Maintains the confidentiality of the information concerning students and dispenses such information only to those who are legitimately entitled to it.

Refrains from subjecting any child to fear, trauma, anxiety, physical punishment, sexual abuse, and mental and emotional harassment.

Keeps a dignified demeanour commensurate with the expectations from a teacher as a role model.

\section{Obligations towards Parents, Community and Society}

Establishes a relationship of trust with parents/guardians in the interest of all round development of students.

Desists from doing anything which is derogatory to the respect of the child or his/her parents/guardians.

* Strives to develop respect for the composite culture of India among students. 
Professional Ethics in Teacher Education . Y

Keeps the country uppermost in mind, refrains from taking part in such activities as may spread feelings of hatred or enmity among different communities, religious or linguistic groups.

\section{Obligations towards the Profession and Colleagues}

Strives for his/her continuous professional development.

* Creates a culture that encourages purposeful collaboration and dialogue among colleagues and stakeholders.

* Takes pride in the teaching profession and treats other members of the profession with respect and dignity.

Refrains from engaging himself/herself in private tuition or private teaching activity,

* Refrains from accepting any gift, or favour that might impair or appear to influence professional decisions or actions.

* Refrains from making unsubstantiated allegations against colleagues or higher authorities.

* Avoids making derogatory statements about colleagues, especially in the presence of pupils, other teachers, officials or parents.

- Respects the professional standing and opinions of his/her colleagues.

* Maintains confidentiality of information concerning colleagues and dispenses such information only when authorized to do so.

\section{REFERENCES}

Adams, C. 2005. Comments made at the GTCE ‘Battle of Ideas' Conference 29-30 October.

Adnett, N. and Davies, P. 2003. Schooling reforms in England: from quasi-markets to competition ? Journal of Education Policy, 18(4) 393-406.

Davies, C. 1996. The sociology of professions and the profession of gender Sociology, 30: 661-78.

Gamble, A. 1988. The Free Economy and the Strong State, London: Macmillan.

Gale, T. and Densmore, K. 2000. Just Schooling: Explorations in the cultural politics of teaching, Buckingham: Open University Press.

Hall, C. and Schulz, R. 2003. Tensions in teaching and teacher education: professionalism and professionalization in England and Canada. Compare, 33(3): 370-83.

Sachs, J. 2003. Teacher professional standards: controlling or developing teaching? Teachers $\mathcal{E}$ Teaching: Theory and Practice, 9(2) 175-86.

Webb, R., Vulliamy, G., Hamalainen, S., Sarja, A., Kmonen, E. and Nevalainen, R. 2004. A comparative analysis of primary teacher professionalism in England and Finland, Comparative Education, 40(1): 83-107. 
